\title{
MRNA Transport Gene
}

National Cancer Institute

\section{Source}

National Cancer Institute. mRNA Transport Gene. NCI Thesaurus. Code C54550.

An RNA transport gene that encodes a protein specifically involved in the transport of mRNA. 